\title{
Growth changes of the stout razor clam Tagelus plebeius (Lightfoot, 1786) under different salinities in SW Atlantic estuaries
}

\author{
Mariana S. Addino $^{\mathrm{a}, *, 1}$, María F. Alvarez ${ }^{\mathrm{a}, 2}$, Thomas Brey ${ }^{\mathrm{b}, \mathrm{c}}$, Oscar Iribarne ${ }^{\mathrm{a}}$, \\ Betina J. Lomovasky ${ }^{\mathrm{a}}$ \\ ${ }^{a}$ Instituto de Investigaciones Marinas y Costeras (IIMyC), Facultad de Ciencias Exactas y Naturales, Universidad Nacional de Mar del Plata, CONICET, Mar del Plata, \\ Argentina \\ ${ }^{\mathrm{b}}$ Alfred Wegener Institute, Helmholtz Center of Polar and Marine Research, Bremerhaven, Germany \\ ${ }^{\mathrm{c}}$ Helmholtz Institute for Functional Marine Biodiversity, Oldenburg, Germany
}

\section{A R T I C L E I N F O}

\section{Keywords:}

Tagelus plebeius

Growth

Condition index

Salinity

\begin{abstract}
A B S T R A C T
Estuarine abiotic characteristics vary with tidal variations and fresh water input, both driven by climatic conditions and often cyclical climatic events. Estuaries are very productive and bivalves often represent a substantial proportion of the biomass with important ecological role. Salinity fluctuation is often a key environmental factor affecting bivalves shell growth and individual condition index (CI), parameters that in turn can be used to show the quality of the environment for one population. The stout razor clam Tagelus plebeius is an euryhaline filterfeeder species that inhabits sandy-silt tidal flats within a wide salinity range. The objective of this study was to evaluate, by survey sampling and in situ transplant experiments among sites with different salinity, whether shell growth and CI of T. plebeius vary with the salinity regime. We hypothesized a higher growth and CI related to the intermediate salinity. Clams and abiotic parameters were sampled in three estuaries of the northern Argentinian coast with different salinity regimes (Bahía Samborombón ( $\left.36^{\circ} 19^{\prime} \mathrm{S}\right)$, Mar Chiquita coastal lagoon $\left(37^{\circ} 32^{\prime} \mathrm{S}\right)$ and Bahía Blanca $\left(38^{\circ} 47^{\prime} \mathrm{S}\right)$ ) and in three sites along the salinity gradient of the Mar Chiquita coastal lagoon where the manipulative experiments were also conducted. Shells were more elongated in sites with lower salinity; but the growth rate (k) and the CI were higher in sites with intermediate salinity. Furthermore, clams transplanted from intermediate salinity sites to those with higher or lower salinity showed a disadvantage in shell growth. Considering the scenario of climatic-driven salinity changes in these estuaries and given that $T$. plebeius is the only native bivalve species in those intertidal zones, having a relevant ecological role and conspicuous fossil presence in Holocene outcrops, our results highlight the relevance of this clam as a valuable target for future studies on conservation biology and paleobiology.
\end{abstract}

\section{Introduction}

In estuarine systems, abiotic characteristics such as water temperature, flow, $\mathrm{pH}$, salinity and oxygen vary periodically with the tidal water influence and fresh water input, and seasonally (e.g. rainfall and winds, Molles, 2002) and cyclical climatic conditions (e.g. El Niño Southern Oscillation - ENSO-, Grimm et al., 2000). In spite of these stressful conditions, these areas constitute refuge and breeding zones for fishes, birds and many benthic invertebrates (Molles, 2002). Bivalves often account for the larger proportion of the biomass in estuarine soft bottom sediments (Bachelet, 1980; Barnes, 2005; Seitz et al., 2006). They are the main food source for several vertebrate species (Leguerrier et al., 2003), playing an important role as habitat modifiers (e.g., bentho-pelagic coupling, Norkko et al., 2006; water transport in sediments, Forster and Zettler, 2004; engineering ecosystems, Jones et al., 1994) and being also of great commercial interest in

\footnotetext{
Abbreviations: SC, San Clemente; MC, Mar Chiquita; BB, Bahía Blanca; SG, San Gabriel; C, Celpa; M, Mouth; AGR, Absolute Growth Rate

* Corresponding author at: Instituto de Investigaciones Marinas y Costeras (IIMyC), Facultad de Ciencias Exactas y Naturales, Universidad Nacional de Mar del Plata, CONICET, Rodriguez Peña 4046, Casilla de Correo 1260, Mar del Plata 7600, Argentina.

E-mail addresses: maddino@mdp.edu.ar (M.S. Addino), feralvarez@ilpla.edu.ar (M.F. Alvarez), thomas.brey@awi.de (T. Brey), osiriba@mdp.edu.ar (O. Iribarne), lomovask@mdp.edu.ar (B.J. Lomovasky).

${ }^{1}$ Present address: Instituto de Investigaciones Marinas y Costeras (IIMyC), CONICET- UNMDP, Grupo de Ecología y Paleoecología de Ambientes Acuáticos Continentales. Instituto de Geología de Costas y del Cuaternario (IGCyC), UNMDP-CIC.

${ }^{2}$ Present address: Laboratorio Cuenca del Salado, Instituto de Limnología “Dr. Raúl A. Ringuelet”, (ILPLA, CONICET - UNLP).
} 
many coastal areas (Gosling, 2003). Thus, the knowledge of the effects of environmental stress on the bivalves' biological characteristics is important for their management and also to understand the processes structuring communities where they play a key role.

Estuarine sessile bivalves can tolerate a wide range of environmental fluctuation but affecting some of their life history traits (Gosling, 2003). In fact, temperature, salinity, food availability, water flow and sediment characteristics have different effects on growth rate (Lenihan et al., 1996), mortality (Shriver et al., 2002) and the reproductive effort (Azouzi et al., 2002). Salinity fluctuation is often the environmental key factor affecting those features (Shriver et al., 2002; Bray et al., 1994; Montagna et al., 2008). Bivalves respond immediately to salinity changes by closing their shells to isolate themselves from the external environment (Hawkins and Bayne, 1992); however, these changes affect characteristics such as shell chemistry (mussels, Klein, 1996), mortality rates (scallops, Barnes, 2005), parasite infection (Volety, 1995), shell growth (oysters, Brown, 1988) and burring activity and growth (clams, Nakamura et al., 2005). Shell shape and ornamentation may also vary with salinity within a species (Barnes, 2005). As a consequence of these salinity effects, variations in the shell growth parameters and also those related to soft tissue (e.g., condition index; Saxby, 2002, Marsden, 2004) may indicate the environmental quality for the species.

Cyclical climatic events often have a large influence in estuaries and coastal lagoons (e.g. Grimm et al., 2000). For example, the El Niño Southern Oscillation (ENSO) heavily modifies the rainfall patterns in coastal areas of South America (Grimm and Tedeschi, 2009; Canepuccia et al., 2010). The El Niño phase generates a rainfall increment accompanied by an accentuation of temperature extremes (Brescia et al., 1998) increasing the river flows (Amarasekera et al., 1997) with a consequent salinity decrease in estuaries and coastal marine areas (Garcia et al., 2004; Piola et al., 2008). The opposite occurs during the La Niña phase with a rainfall decrease generating drought (Grimm and Tedeschi, 2009). According the research of the importance of bivalves in estuarine communities and this scenario of climatic driven abiotic changes, it is important to understand how bivalves' growth and body conditions respond to changes in salinity. This information can then be used to infer future changes under a climate change scenario (change in rain pattern in this case) and can be applied to conservation biology and paleobiology studies.

The stout razor clam Tagelus plebeius is an euryhaline filter-feeder species that inhabits tidal flats with cohesive sandy-silt sediments (Holland and Dean, 1977) within a salinity range from marine (34.4) to brackish (3.6) conditions (Abrahão et al., 2010); but it may be found also in hypersaline (41) conditions (Addino, 2014). It is present along the American Atlantic coast from Cape Cod, Massachusetts $\left(42^{\circ} \mathrm{N}\right.$, USA, Leal, 2002) to the Northern Argentinean Patagonia (41 ${ }^{\circ}$ S, Olivier et al., 1972). In the northern coast of Argentina T. plebeius inhabits at least four estuaries with very different salinity patterns, mainly related to the continental freshwater input: Bahía Samborombón $\left(36^{\circ} 19^{\prime} S\right)$, Mar Chiquita coastal lagoon $\left(37^{\circ} 32^{\prime} \mathrm{S}\right)$, Quequén Grande ( $\left.38^{\circ} 34^{\prime} \mathrm{S}\right)$ and Bahía Blanca $\left(38^{\circ} 47^{\prime} \mathrm{S}\right)$. Tagelus plebeius is the only native bivalve species inhabiting the intertidal areas of these estuaries. Through siphon holes and surrounding depressions this clam enhances habitat complexity increasing sediment organic matter content, microphytobenthic and meiofaunal community abundance (Alvarez et al., 2015) and also modifying juvenile crab (Neohelice granulata) distribution (Gutierrez and Iribarne, 2004). At the same time, crabs have different effects on clams' performance (Lomovasky et al., 2006) and feeding activity (Addino et al., 2016). This clam is the main prey item for the oystercatcher (Haematopus palliatus; Banchmann and Martínez, 1999), which would be the final host of gymnophallid parasites that use these clams as intermediate hosts (Vázquez et al., 2006) modifying their predation rate (Addino et al., 2010). Actually, predation by oystercatchers would explain the extended accumulations of living position fossil shells (Iribarne et al., 1998) which also enhance diversity and abundance of the benthic community inside them (Gutierrez and Iribarne, 1999). These shell accumulations make this clam one of the most common fossil bivalve species in the Holocene outcrops; being often used as indicator of paleoenvironmental conditions (e.g., Schnack et al., 1982; Martínez and Del Río, 2005). Also, in SW Atlantic coastal areas this clam supports small scale artisanal and commercial fisheries with consequences in surrounding habitats (Menafra et al., 2006). These interactions in numerous ecological processes show that this species is a valuable object of study since population modifications may impact diverse community components.

Thus, the objective of this study is to evaluate, by means of sampling and in situ transplant experiments, whether shell growth and condition index of T. plebeius vary in the different salinity regimes. Given that estuarine clams have an optimum and a critical salinity for growth (Newell, 1991) and that they are restricted to estuaries (Holland and Dean, 1977); we hypothesized that, within the salinity range of the studied sites, the shell growth and the condition index of T.plebeius are higher in intermediate salinities than in more extreme salinity conditions.

\section{Material and methods}

\subsection{Study site}

Sampling and experiments with T. plebeius were carried out between December 2008 and May 2011, in unvegetated mudflats in three estuaries of the northern coast of Argentina (Fig. 1A). These are from north to south: Bahía Samborombón, in its southern extreme close to San Clemente del Tuyú town (hereafter SC), Mar Chiquita coastal lagoon, along its entrance channel (hereafter MC) and Bahía Blanca, in the middle outer reach of the principal channel (hereafter BB). The three estuaries show a semidiurnal tidal regime, although tidal amplitude increases to the south, being microtidal in SC and MC and mesotidal in BB (mean amplitude $0.80 \mathrm{~m}$, Bértola et al., 1998; $0.81 \mathrm{~m}$, Isla and Gaido, 2001 and 3.18 m, Perillo and Piccolo, 1999; respectively). Annual precipitation regime decreases also to the south, indeed estuarine freshwater inflow is lower in BB (Isacch et al., 2006). In addition, the SC drainage watershed is affected by three small rivers (Salado, Samborombón and Ajó) and several interconnected lagoons and creeks which generate a much higher freshwater input to the estuary when compared with both MC and BB (Bértola, 1994; Piccolo and Perillo, 1997).

Inside MC estuary, weather conditions (precipitation, wind direction and intensity and storm occurrence) have a short-term, strong influence on water dynamics which in addition to tides results in highly variable salinity but with a marked gradient from marine water near the lagoon mouth to mixed freshwater in the lagoon header (Reta et al., 2001). Moreover, given the shallow depth of the water body $(1.5 \mathrm{~m}$, Lanfredi et al., 1981) and the winds in the area, there is not vertical stratification of the water column in any time through the year (Marcovecchio et al., 2006). Thus, three sites along this salinity gradient inside MC lagoon were chosen (see Fig. 1B), in ascendant order of salinity: lagoon body (named San Gabriel, located approximately $6 \mathrm{~km}$ from the mouth, SG), inlet channel (named CELPA, located approximately $2.5 \mathrm{~km}$ from the mouth, C) and mouth (M).

For environmental variables and clam population characteristics (see next sections), comparisons were made at two different scales: 1) regional scale, represented by the comparison among estuaries and 2) local scale, represented by the comparison among sites within the Mar Chiquita coastal lagoon (MC).

\subsection{Physical variables}

Sampling of abiotic variables were carried out in the medium intertidal level (following Lomovasky et al., 2016), where along the semidiurnal tide cycle the water covers when flooding and uncover 


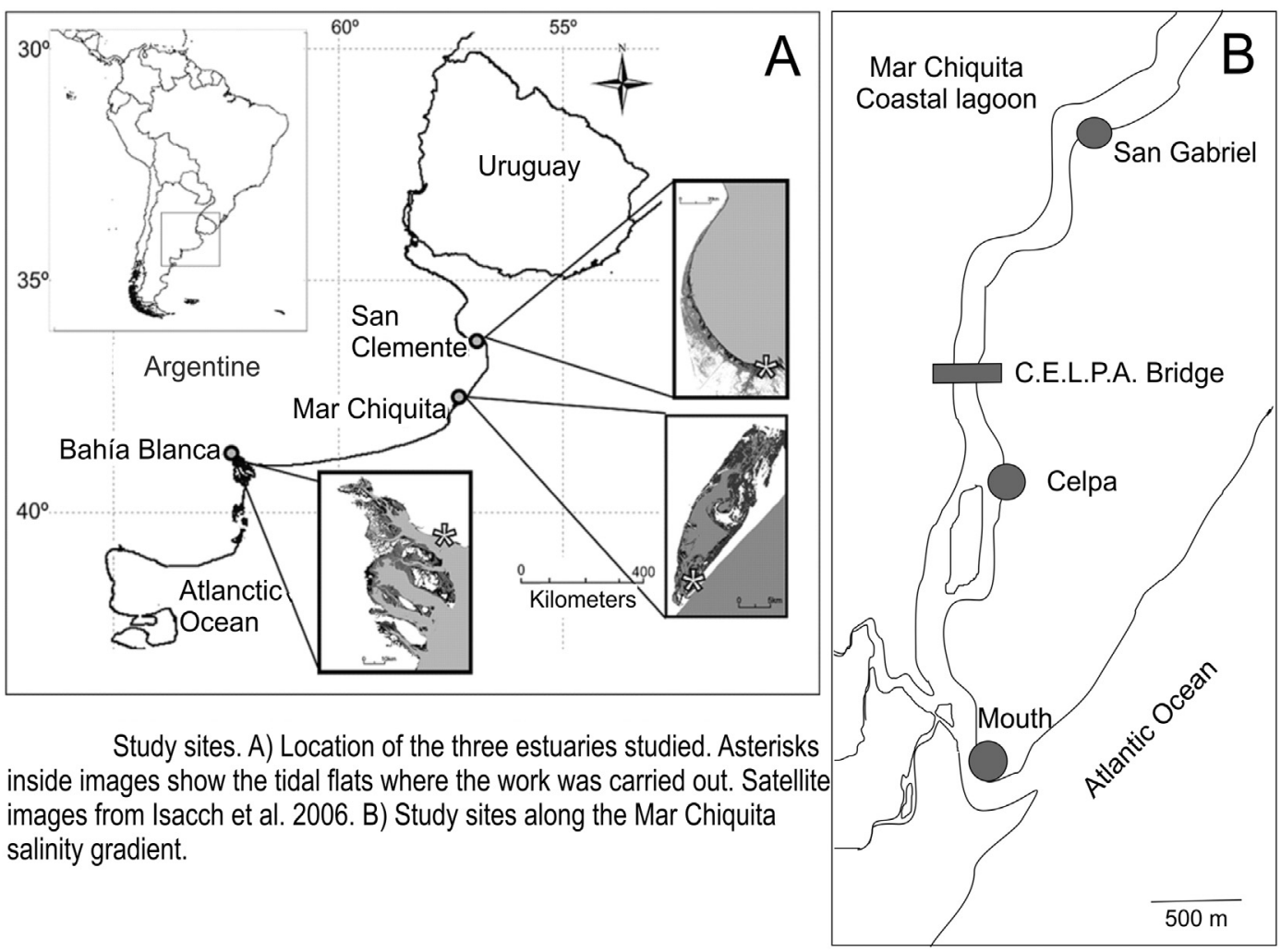

Fig. 1. Legend is embedded into the fig. (2 columns).

when ebbing in every tidal cycle. To describe salinity and to verify the patterns reported in the literature (Piccolo and Perillo, 1997; Reta et al., 2001; Isacch et al., 2006), water samples were taken monthly or bimonthly depending on logistical constrains and salinity was measured with a handheld refractometer. Samples were taken during flooding tide and at $15 \mathrm{~cm}$ below the water surface, with $3 \mathrm{ml}$ plastic tubes in each estuary (spring-summer seasons from 2008 to 2011, between 12 and 15 samples in total per estuary) and in each site within the salinity gradient of MC (in spring-summer seasons from 2009 to 2011, 14 samples per site). For all comparisons among estuaries, MC was represented by samples from $\mathrm{C}$ because it is located approximately in the centre of the salinity gradient (see Section 2.1 and Fig. 1B for details). Hereafter, all comparisons regarding environmental variables and clam population characteristics, for both regional and local scales, were made by one-way ANOVAs. The Factor was "Estuary" or "Site", respectively; and individual clams were the replicates into each estuary or site.

To distinguish the effect of salinity from other environmental variables, temperature, sediment grain size distribution, chlorophyll $a$ $\left(\mathrm{Chl}_{\mathrm{a}}\right)$, total particulate matter (TPM) and particulate organic matter (POM) were measured. Temperature data loggers (iButton, Maxim Integrated Products, CA, USA) were set up in each estuary and each site within MC gradient in the mudflat. Temperature data $\left( \pm 0.5^{\circ} \mathrm{C}\right)$ was recorded at intervals of $120 \mathrm{~min}$, from March to October 2010 according to the data storage capacity of the iButton. Temperature data were averaged for each day and the null hypothesis of no differences in mean daily sediment surface temperature among estuaries was evaluated by ANOVA. Before this analysis (and hereafter) the validity of the assumptions was evaluated and if necessary monotonic transformations were applied (Zar, 1999). Within MC salinity gradient, mean daily sediment surface temperature was compared only between SG and C by $t$ test (Zar, 1999) given that the data loggers in $\mathrm{M}$ were lost by tides.

To analyse grain size distribution, five sediment cores $(5 \mathrm{~cm}$ diameter and $20 \mathrm{~cm}$ depth) were randomly taken in each estuary. Sediment samples were wet-sieved through six steel sieves of $2,1,0.5,0.25$,
$0.125,0.063 \mathrm{~mm}$; the fraction $<0.063 \mathrm{~mm}$ was also preserved. The material retained in each sieve was dried at $80^{\circ} \mathrm{C}$ to constant weight (precision $\pm 0.01 \mathrm{~g}$ ). Weight percentages of sand $(<1$ and $>0.063$ $\mathrm{mm})$ and silt-clay $(<0.063 \mathrm{~mm})$ were calculated for each sample. The null hypothesis of lack of differences in mean percentage of sand and silt-clay among estuaries was evaluated by ANOVA (Zar, 1999).

To test the effect of salinity on clams' growth, we performed a transplant experiment among sites within MC (see Section 2.4 for details). Phytoplankton (Botto et al., 2005) and particulate organic matter (Abrahão et al., 2010) are the main food sources for this clam. Thus, although previous studies found that $\mathrm{Chl}_{\mathrm{a}}$ remains high throughout the year along the MC coastal lagoon (De Marco et al., 2005; Marcovecchio et al., 2006), parallel to the experiment the in vivo $\mathrm{Chl}_{\mathrm{a}}\left(\mu \mathrm{l}^{-1}\right)$, total particulate material (TPM, $\mathrm{g}^{-1}$ ) and particulate organic matter (POM, $\mathrm{g}^{-1}$ ) in the water column were measured at each site. Samples were taken weekly during the last 2 months of the experimental period. Water samples of tree $\mathrm{ml}$ were taken and immediately after, $\mathrm{Chl}_{\mathrm{a}}$ was measured with an Aquafluor handheld Fluorometer (Turner Design, Model 8000-01, detection range: $\mathrm{Chl}_{\mathrm{a}}=0.05-300 \mu \mathrm{g}^{-1}$; following Bruschetti et al., 2008). To measure TPM and POM water samples were taken with $500 \mathrm{ml}$ plastic bottles. Samples were filtered onto preweighed, $4.7 \mathrm{~cm}$ diameter and $1.2 \mu \mathrm{m}$ mesh size, glass-fiber filters GF/C Whatman. Each filter with the retained material was dried at $80^{\circ} \mathrm{C}$ to constant weight (precision $\pm 0.01 \mathrm{~g}$ ) and then burned in a muffle furnace at $450{ }^{\circ} \mathrm{C}$ for $8 \mathrm{~h}$ to calculate total POM. The null hypotheses of no difference in mean $\mathrm{Chl}_{\mathrm{a}}$, TPM and POM among sites within MC were evaluated in each case by ANOVA (Zar, 1999).

\subsection{Shell morphometric relationships, shell growth rates and condition index of Tagelus plebeius}

Random sampling of clams was carried out at the medium intertidal level between October 2007 and January 2008. For regional sampling, 255 clams were extracted in the three estuaries: 62 from SC, 74 from MC and 119 from BB. Along the MC salinity gradient 192 clams were 
extracted: 57 from SG, 74 from C and 61 from M. Shell length (hereafter $\mathrm{L}$, anterior-posterior axis) and shell height (hereafter $\mathrm{H}$, umbo-ventral edge axis) of all individuals were measured with an electronic calliper (precision $\pm 0.01 \mathrm{~mm}$ ). The relationship between $\mathrm{L}$ and $\mathrm{H}$ was evaluated by simple regression models and then compared among estuaries ( $\mathrm{H}$ range: $13.06-23.15 \mathrm{~mm}$ ) and sites along the $\mathrm{MC}$ gradient ( $\mathrm{H}$ range: 13.08-23.15 mm) by ANCOVA using $\mathrm{H}$ as covariate. For this analysis and hereafter Type III sum of squares for unbalanced data was applied and the assumption of parallelisms between slopes was evaluated (Zar, 1999).

Tagelus plebeius forms annual internal shell growth bands (Lomovasky et al., 2005; Lomovasky et al., 2016) represented by opaque growth bands (fast growth) and translucent growth lines (slow growth; see Lomovasky et al., 2016 for details) allowing the determination of clam age and development of the corresponding growth models as size-age curves (following Richardson, 2001). Each left shell was embedded in polyester resin, sectioned along the maximum $\mathrm{H}$ growth axis using a saw with a diamond blade and the cross-sections were polished on lapidary wheels using sandpaper of 400, 600, 1200, 2500 and 4000 grade (following Lomovasky et al., 2016). The number of translucent internal growth lines (Jones et al., 1990) was counted to assess the age (years) of each individual using a stereo microscope (following age validation made by Lomovasky et al., 2016). From the growth models commonly used for bivalves (e.g., Cruz-Vásquez et al., 2012), only Von Bertalanffy (1938) and Logistic (Ricker, 1975) could be statistically compared. According to Akaike information criterion (Akaike, 1973) and Akaike weight ( $\mathrm{W}_{\mathrm{AIC}}$, Franklin et al., 2001), the Logistic model was the model that best fit the data except in $\mathrm{C}\left(\mathrm{W}_{\mathrm{AIC}}\right.$ Von Bertalanffy/Logistic = SC: 48/51, MC: 46/54, BB: 31/69, SG: 26/ 74, C: 55/45, M: 12/88). Nevertheless, to allow further comparisons, the Logistic model was chosen due to the $\mathrm{W}_{\mathrm{AIC}}$ differences were very small. Hence, the growth parameters $\mathrm{k}, \mathrm{L} \infty$ and $\mathrm{t}_{0}$ of the Logistic model were compared pair wise among estuaries (SC vs. MC, SC vs. BB, MC vs. $\mathrm{BB}$ ) and among sites within MC (SG vs. C, SG vs. M and C vs. M) using maximum likelihood ratio tests (Cerrato, 1990).

To evaluate differences in soft tissue condition of clams among different sites, the condition index (hereafter $\mathrm{CI}$ ) of each clam was calculated using the dry weight of soft tissue (DW, dried at $80^{\circ}$ to constant weight) and the total length (L) by means of the following equation (following Clausen and Riisgård, 1996):

$\mathrm{CI}=\mathrm{DW} \cdot \mathrm{L}^{-\mathrm{b}}$

where " $\mathrm{b}$ " is the slope of the regression curve between L and DW. There were two estimates of " $\mathrm{b}$ ", one for the calculation of CI for clams to be compared among estuaries and one for clams to be compared among sites from MC; thus, the scales of the respective comparisons are different. The null hypotheses of no difference in mean clams' CI among the 3 estuaries and the 3 sites within MC were tested using ANOVA, followed by Tukey HSD for a-posteriori comparisons (Zar, 1999).

\subsection{Shell growth of Tagelus plebeius in transplant experiments along the MC salinity gradient}

To evaluate the effect of salinity on shell growth, a transplant experiment was performed during one growth season, from November 2010 (late spring) to May 2011 (early autumn). Due to logistical constrains transplant experiments were carried out only at the three sites within MC. One hundred and twenty clams were extracted at each site along the MC gradient (i.e., SG, C and M). Shells were measured in length (initial length, $\mathrm{L}_{\mathrm{i}}$ ) and marked with a plastic number adhered to the periostracum surface with super glue (cyanoacrylate) to be identified at the end of the experiment. Forty clams were transplanted from each site to the others as follows: from SG to C and M (SG-C, SG-M), from C to SG and M (C-SG, C-M) and from M to SG and C (M-SG, M-C); with the correspondent transplant control (SG-SG, C-C, M-M). At the end of the experiment 216 live clams were recovered and measured again (final length, $\mathrm{L}_{\mathrm{f}}$ ). Due to logistical constrains not all the clams were transplanted at the same date thus, an absolute growth rate was calculated (AGR, growth per time unit $\left(\mathrm{mm} \mathrm{day}^{-1}\right)$ ) following Gardner and Thompson (2001):

$\mathrm{AGR}=\left(\mathrm{L}_{\mathrm{f}}-\mathrm{L}_{\mathrm{i}}\right) \mathrm{t}^{-1}$

where " $\mathrm{t}$ " is the number of days elapsed during the experiment. Given that the growth slows down as the clams are larger, we looked for the relationship between AGR and $\mathrm{L}_{\mathrm{i}}$ by means of simple regression models for each set of transplanted clams. These regression models were then compared among destination sites, for each origin site. For clams from SG and M ANCOVA could be done using $\mathrm{L}_{\mathrm{i}}$ as covariate (2 ANCOVA in total). For clams from C, given that the assumption of parallelisms was not fulfilled, we analyzed the slopes differences. For each comparison $\mathrm{L}_{\mathrm{i}}$ ranges were adjusted accordingly to: $37.28-48.55 \mathrm{~mm}$ for clams from SG, 26.12-50.41 for clams from C and 24.65-46.03 for clams from M.

\section{Results}

\subsection{Physical variables}

There was a salinity gradient from lower values in SC to higher values in $\mathrm{BB}$ and intermediate values with wider spread in MC generating some overlapping with SC and BB (Fig. 2 A, Table 1). The same was found for the three sites along MC gradient, from lower values in SG to higher values in $\mathrm{M}$ although with a higher overlap of values (Fig. 2B, Table 1). This data distribution supports the gradient reported in the literature. The sediment surface temperature was lower in MC

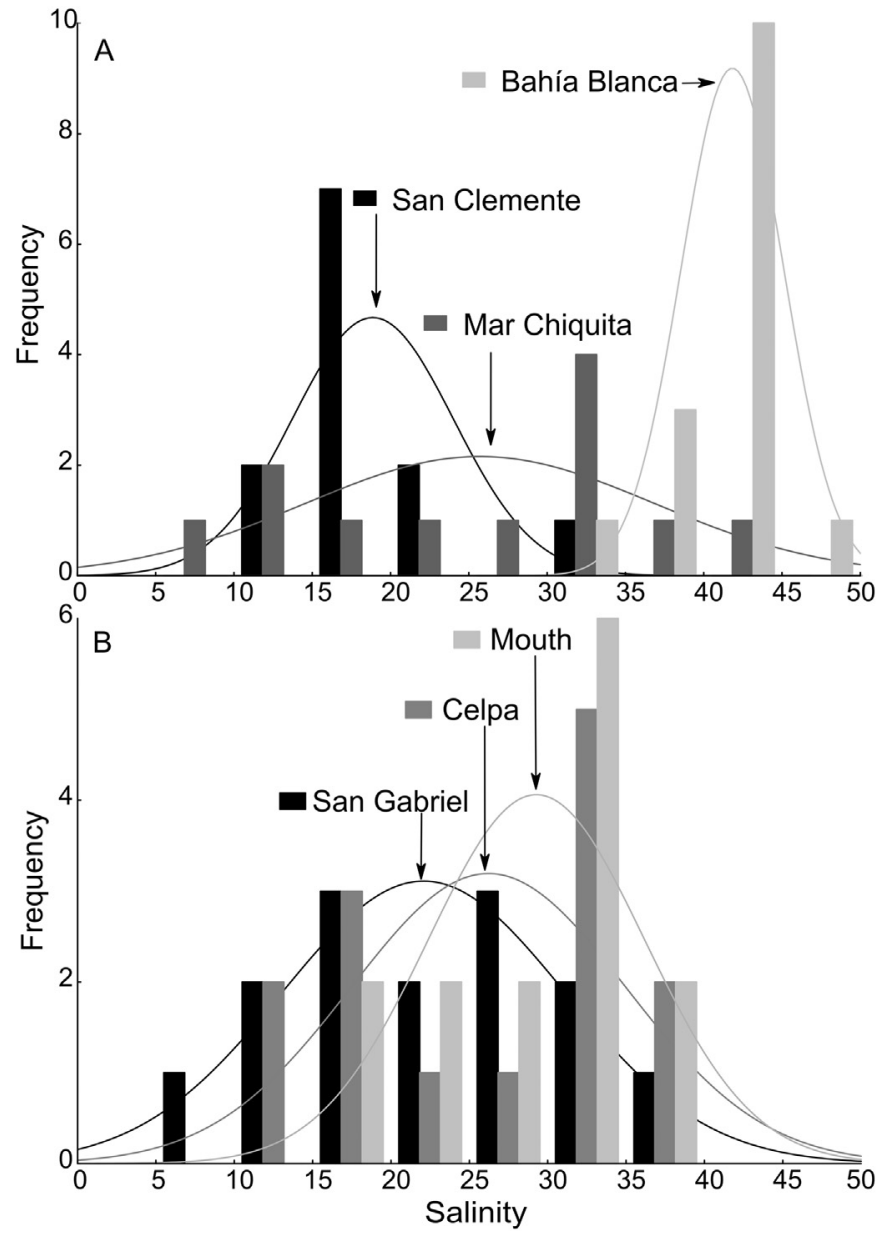

Fig. 2. Salinity data distribution: (A) the three estuaries and (B) the three sites along Mar Chiquita coastal lagoon salinity gradient. (1 column). 
Table 1

Descriptive statistic for salinity in the three estuaries ( $\mathrm{SC}=$ San Clemente, MC = Mar Chiquita, BB = Bahía Blanca) and each site along the Mar Chiquita salinity gradient ( $\mathrm{SG}=$ San Gabriel, $\mathrm{C}=$ Celpa, $\mathrm{M}=$ Mouth). SD: Standard deviation. Confidence Interval: 95\% Mean Confidence Interval.

\begin{tabular}{llllllll}
\hline Estuary & Site & Mean & SD & $\begin{array}{l}\text { Confidence } \\
\text { interval }\end{array}$ & Median & Minimum & Maximum \\
\hline SC & & 18.8 & 5.1 & $15.5-22.0$ & 17.90 & 11.00 & 30.80 \\
& SG & 21.9 & 8.9 & $16.7-27.1$ & 22.90 & 5.60 & 36.00 \\
MC & C & 26.0 & 8.7 & $21.0-31.1$ & 29.13 & 12.00 & 36.00 \\
& M & 29.1 & 6.9 & $25.1-33.1$ & 31.80 & 17.00 & 35.25 \\
BB & & 41.6 & 3.3 & $39.8-43.4$ & 41.60 & 34.40 & 47.20 \\
& & & & & & & \\
\hline
\end{tabular}

than in the other two estuaries $\left(\mathrm{H}_{(2,507)}=48.09, \mathrm{p}<.001\right)$, but it did not differ among sites along the MC lagoon $\left(\mathrm{t}_{(1,338)}=0.36, \mathrm{p}=.72\right.$; Table 2). The percentage of sand was smaller in BB than in the other two estuaries $\left(\mathrm{F}_{(2,12)}=6, \mathrm{p}=.016\right)$ and accordingly the percentage of silt-clay was higher in $\mathrm{BB}\left(\mathrm{F}_{(2,12)}=5.44, \mathrm{p}=.021\right.$; Table 2). Mean Chl as well as TPM and POM did not differ among sites along the MC gradient $\left(\mathrm{F}_{(2,18)}=0.37,0.95\right.$ and $0.48, \mathrm{p}=.68, .40, .63$, respectively; Table 2).

\subsection{Shell morphometric relationships, shell growth rates and condition index of Tagelus plebeius}

The length and height of clams were linearly related in the three estuaries (SC: $\mathrm{F}=507, \mathrm{r}^{2}=0.86$; $\mathrm{MC}$ : $\mathrm{F}=588, \mathrm{r}^{2}=0.89$; $\mathrm{BB}$ : $\mathrm{F}=903$, $\mathrm{r}^{2}=0.89$; all $\left.\mathrm{p}<.001\right)$ as well as in the three sites along the MC gradient (SG: $\mathrm{F}=316, \mathrm{r}^{2}=0.92 ; \mathrm{C}: \mathrm{F}=588, \mathrm{r}^{2}=0.94$; $\mathrm{M}$ : $\mathrm{F}=337$, $\mathrm{r}^{2}=0.92$; all $\left.\mathrm{p}<.001\right)$. The slopes were different among estuaries $\left(\mathrm{F}_{(2,227)}=4.75, \mathrm{p}=.009\right)$ being higher in SC than in the other estuaries. It indicates that shells were more elongated there; so for a given shell height the length was higher (Fig. 3A). The intercepts were different among sites along the MC gradient $\left(\mathrm{F}_{(2,160)}=5.22, \mathrm{p}=.006\right)$, being higher in SG and $\mathrm{C}$ than in $\mathrm{M}$, indicating that clams were more elongated in SG and C (Fig. 3B).

The age of clams ranged between 3 and 17 years old. The parameter $\mathrm{k}$ was higher and $\mathrm{L} \infty$ was lower in MC than in the other two estuaries (Table 3) indicating that these clams had a faster growth in the first years, reaching a smaller but earlier asymptotic length than clams from SC and BB (Table 4). $\mathrm{T}_{0}$ was smaller in BB than in the other two estuaries. The same growth pattern was observed among sites along the MC gradient, since $\mathrm{k}$ was higher and $\mathrm{L} \infty$ was lower in $\mathrm{C}$ than in SG and $\mathrm{M}$, while $t_{0}$ was lower in $C$ than in SG (Tables 3 and 4, Fig. 4A and B).

Mean CI differed among estuaries $\left(\mathrm{F}_{(2,225)}=152, \mathrm{p}<.0001\right)$ showing that MC $>$ SC $>$ BB (Tukey HSD, $\mathrm{p}<.05$, Fig. 5A). Also, CI differed among sites along the $\mathrm{MC}$ gradient $\left(\mathrm{F}_{(2,}\right.$ 159) $=148$, $\mathrm{p}<.0001$ ) being $\mathrm{C}>\mathrm{M}>$ SG (Tukey HSD, $\mathrm{p}<.05$, Fig. 5B).

\subsection{Shell growth of Tagelus plebeius in transplant experiments along the MC salinity gradient}

The AGR showed negative linear relationships with the $L_{i}$ for all transplants (Table 5, Fig. 6). For clams from SG the ANCOVA showed
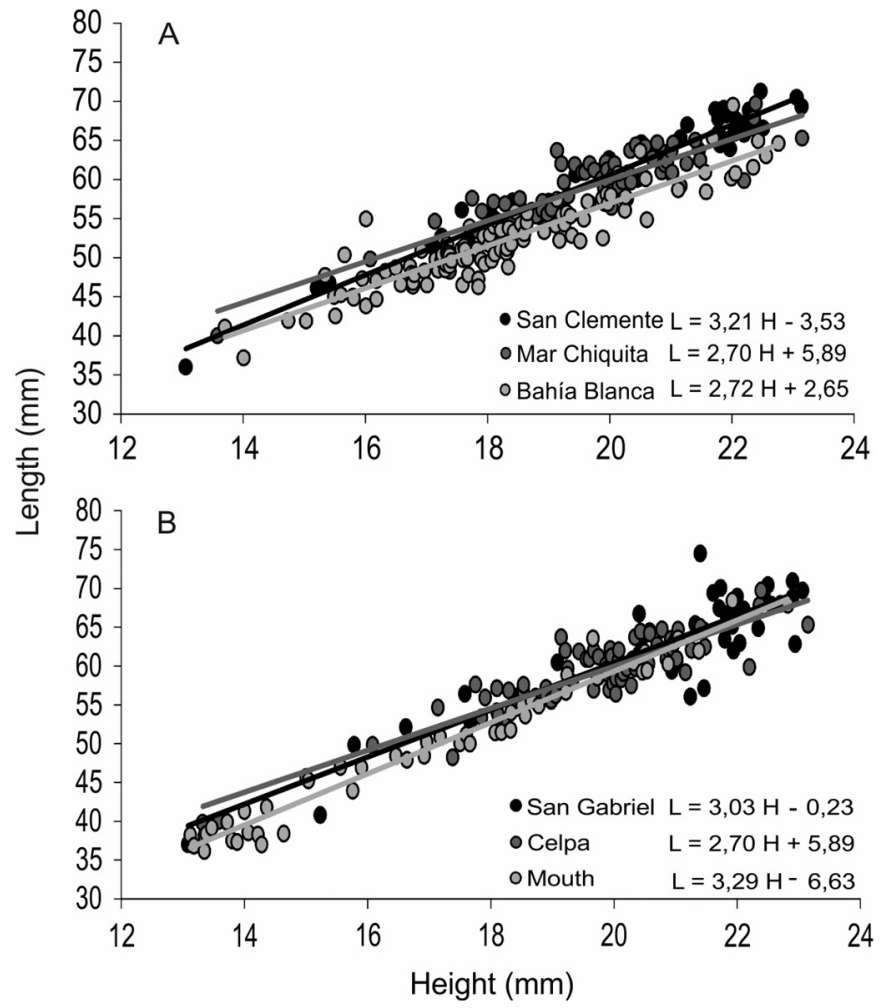

Fig. 3. Relationships between length and height of clams: (A) the three estuaries and (B) the three sites along the Mar Chiquita coastal lagoon salinity gradient. Regression equation for each location is given. (1 column).

Table 3

Comparison of Logistic model parameters $\left(\mathrm{L}_{\mathrm{t}}=\mathrm{L} \infty /\left(1+\mathrm{e}^{-\mathrm{k}_{*}(\mathrm{t}-\mathrm{t} 0)}\right)\right)$ by pairs between estuaries ( $\mathrm{SC}=\mathrm{San}$ Clemente, $\mathrm{MC}=$ Mar Chiquita, $\mathrm{BB}=$ Bahía Blanca) and sites along the Mar Chiquita salinity gradient (SG = San Gabriel, $\mathrm{C}=$ Celpa, $\mathrm{M}=$ mouth); by means of Maximum likelihood ratio analysis. Bolded values indicate significant differences.

\begin{tabular}{llllllll}
\hline \multicolumn{1}{c}{ Comparison between: } & & \multicolumn{5}{c}{ Parameters compared } \\
\hline & & L $\infty$ & & $\mathrm{k}$ & & $\mathrm{t}_{0}$ & \\
& & $X^{2}$ & p-value & $X^{2}$ & p-value & $X^{2}$ & p-value \\
\multirow{4}{*}{ Estuaries } & SC-MC & 20.11 & $<.001$ & 10.18 & $<.01$ & 3.24 & .07 \\
& SC-BB & 0.24 & .62 & 1.02 & .31 & 10.15 & $<.01$ \\
Sites & MC-BB & 3.92 & .047 & 11.68 & $<.001$ & 14.73 & $<.001$ \\
along MC & SG-C & 21.18 & $<.001$ & 12.69 & $<.001$ & 3.84 & .049 \\
& SG-M & 0.16 & .68 & 1.17 & .28 & 0.78 & .38 \\
& C-M & 11.36 & $<.001$ & 17.06 & $<.001$ & 1.89 & .17 \\
\hline
\end{tabular}

that the intercepts were higher in $\mathrm{M}$ than in $\mathrm{C}$, indicating an advantage of high salinity $\left(\mathrm{F}_{(2,49)}=5.12, \mathrm{p}=.009\right)$. For clams from $\mathrm{M}$ the ANCOVA showed that the intercepts were higher in $\mathrm{M}$ than in $\mathrm{C}$ and SG indicating a disadvantage of low salinity $\left(\mathrm{F}_{(2,48)}=5.64, \mathrm{p}=.006\right)$. For clams from $C$ the slope was lower in $C$ than in $S G$ and $M\left(F_{(2,69)}=3.54\right.$, $\mathrm{p}=.03$ ) indicating smaller diminution of AGR as $\mathrm{L}_{\mathrm{i}}$ increased in the origin site. This means a negative effect of both low and high salinity for

Table 2

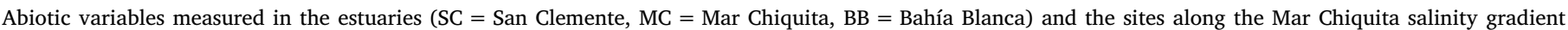
(SG = San Gabriel, C = Celpa, M = Mouth). Mean values with the correspondent standard deviation (SD) are shown.

\begin{tabular}{|c|c|c|c|c|c|c|c|}
\hline Estuary & Site & Temperature $\left({ }^{\circ} \mathrm{C}\right)$ & Sand (\%) & Silt-clay (\%) & $\mathrm{Chl}_{\mathrm{a}}\left(\mu \mathrm{g} \mathrm{l}^{-1}\right)$ & TPM $\left(\mathrm{gl}^{-1}\right)$ & POM $\left(\mathrm{gl}^{-1}\right)$ \\
\hline \multirow[t]{2}{*}{ SC } & - & $15.1(4.5)$ & $82.6(11.7)$ & $15.0(11.6)$ & - & - & - \\
\hline & SG & $11.5(3.9)$ & - & - & $18.6(17.1)$ & $0.10(0.04)$ & $0.02(0.009)$ \\
\hline \multirow[t]{2}{*}{ MC } & $\mathrm{C}$ & $11.7(3.8)$ & $76.7(4.4)$ & $22.5(4.4)$ & $15.8(15.2)$ & $0.13(0.08)$ & $0.02(0.018)$ \\
\hline & M & - & - & - & $11.8(10.1)$ & $0.10(0.02)$ & $0.02(0.007)$ \\
\hline BB & - & $14.3(5.3)$ & $66.3(3.9)$ & $30.9(4.4)$ & - & - & - \\
\hline
\end{tabular}


Table 4

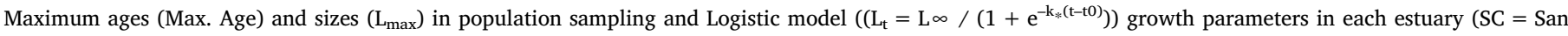

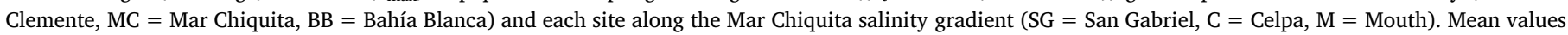
of each parameter $\left(\mathrm{L} \infty, \mathrm{k}, \mathrm{t}_{0}\right)$ with the correspondent $95 \%$ confidence interval (CI) are shown.

\begin{tabular}{|c|c|c|c|c|c|c|}
\hline Estuary & Site & Max. age & Mean $\mathrm{L}^{\infty}(\mathrm{CI})$ & Mean k (CI) & Mean $t_{0}(\mathrm{CI})$ & $\mathrm{L}_{\max }$ \\
\hline \multirow[t]{2}{*}{ SC } & - & 13 & 71.20 (55.40-86.99) & $0.46(-0.15-1.07)$ & $2.97(0.85-5.08)$ & 79.12 \\
\hline & SG & 17 & $73.76(52.26-95.26)$ & $0.36(-0.34-1.05)$ & $5.19(1.66-8.72)$ & 78.40 \\
\hline \multirow[t]{2}{*}{ MC } & $\mathrm{C}$ & 14 & $59.65(52.22-67.08)$ & $1.51(-3.59-6.60)$ & $3.74(2.52-4.96)$ & 69.71 \\
\hline & M & 14 & 71.17 (18.78-123.56) & $0.25(-0.13-0.63)$ & $4.41(-1.63-10.45)$ & 68.41 \\
\hline BB & - & 11 & $67.31(16.48-118.13)$ & $0.29(-0.53-1.11)$ & $0.41(-5.08-5.90)$ & 70.22 \\
\hline
\end{tabular}

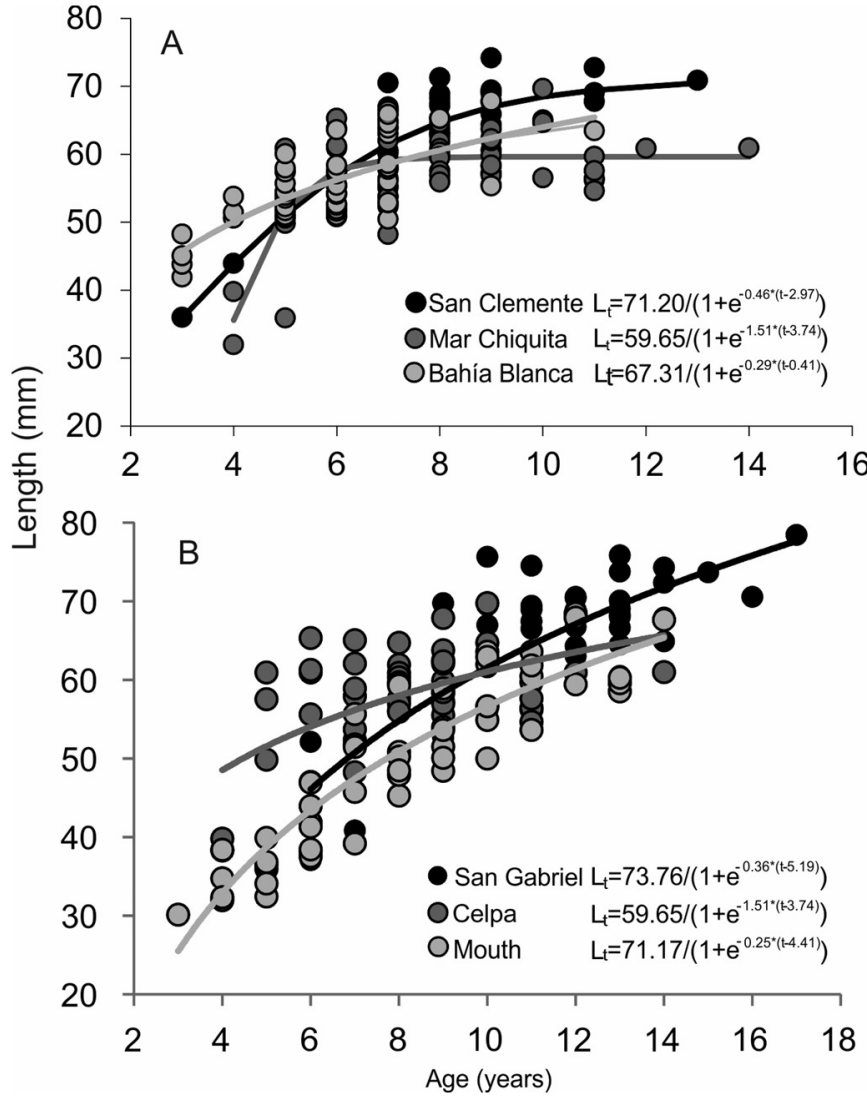

Fig. 4. Shell growth curves: (A) the three estuaries and (B) the three sites along the Mar Chiquita coastal lagoon salinity gradient. The line is the predicted by the Logistic model: $\mathrm{L}_{\mathrm{t}}=\mathrm{L} \infty /\left(1+\mathrm{e}^{-\mathrm{k}_{*}(\mathrm{t}-\mathrm{t} 0)}\right.$. Points are the observed data; model equation for each location is given. (1 column).

C' clams.

\section{Discussion}

The population characteristics of Tagelus plebeius analyzed here indicate that the sites with intermediate salinity are more favourable for their growth and condition index (CI). Clams showed higher growth rate (k), smaller asymptotic length $(\mathrm{L} \infty)$ and higher $\mathrm{CI}$ in the sites with intermediate salinity, that is in the Mar Chiquita coastal lagoon when compared with the other two estuaries and in $\mathrm{C}$ when compared with the other two sites along the MC salinity gradient. Meanwhile, the transplant experiments showed a positive effect of high salinity or a negative effect of low salinity, depending on the origin of the transplanted clams; but clams from the site with intermediate salinity were negatively affected by both the highest and the lowest salinity.

Salinity data found in this study support the patterns reported in the literature for both, the different estuaries (Piccolo and Perillo, 1997) and the gradient along the Mar Chiquita coastal lagoon (Reta et al.,
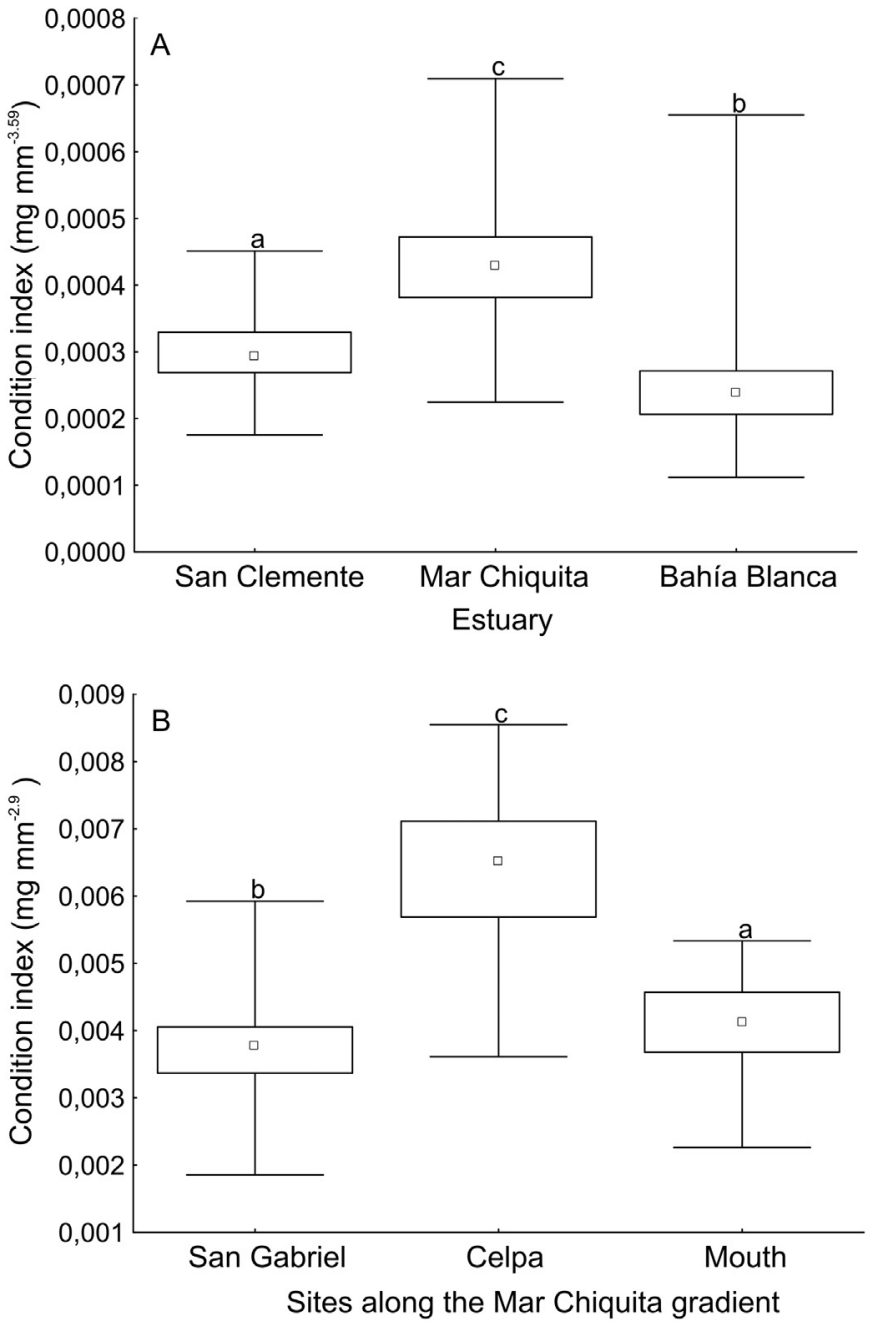

Fig. 5. Condition Index of clams: (A) the three estuaries and (B) the three sites along the Mar Chiquita coastal lagoon salinity gradient. Middle point represents the median, box limits are 25 and 75 percentiles and bars limits indicate minimum and maximum values. Letters indicate differences in ascendant order. (1 column).

2001). At regional scale the annual precipitation regime and consequent freshwater inflow to estuaries decrease from SC to MC and BB (Isacch et al., 2006). Moreover, the SC drainage watershed contributes a much higher freshwater input to the estuary when compared with both MC and BB. This is due to the rivers and several interconnected lagoons and creeks related to it (Bértola, 1994; Piccolo and Perillo, 1997). Thus, salinity values become higher from SC to MC and BB (from north to south) as data distribution showed (Fig. 2A). Inside the Mar Chiquita coastal lagoon, the strong influence of winds can enhance the sea intrusion and shift the conditions from brackish to marine in the upstream locations (e.g. SG). Conversely, a great freshwater discharge 
Table 5

Statistics of the linear regressions for clams' initial length $\left(\mathrm{L}_{\mathrm{ini}}\right)$ and Absolute Rate of Growth (ARG $=a+b \cdot L_{\text {ini }}$ ) in the transplant experiment among sites along the Mar Chiquita salinity gradient, for all transplanted groups of clams. SG: San Gabriel, C: Celpa, M: Mouth.

\begin{tabular}{lllll}
\hline Origin site & Destination site & $\mathrm{F}$ & $\mathrm{p}$-value & $\mathrm{R}^{2}$ \\
\hline SG & SG & 74 & $<.001$ & 0.75 \\
& $\mathrm{C}$ & 16 & $<.001$ & 0.44 \\
& $\mathrm{M}$ & 9 & $<.01$ & 0.37 \\
$\mathrm{C}$ & $\mathrm{SG}$ & 119 & $<.001$ & 0.80 \\
& $\mathrm{C}$ & 74 & $<.001$ & 0.50 \\
& $\mathrm{M}$ & 21 & $<.001$ & 0.54 \\
$\mathrm{M}$ & $\mathrm{SG}$ & 65 & $<.001$ & 0.59 \\
& $\mathrm{C}$ & 157 & $<.001$ & 0.70 \\
& $\mathrm{M}$ & 12 & .03 & 0.46 \\
\hline
\end{tabular}

related to a strong episodic rainfall, which is common in the area (e.g. due to the El Niño, Brescia et al., 1998), can shift marine conditions to brackish conditions at the lagoon entrance (Marcovecchio et al., 2006). These events explain the wide range of salinity values found in each site along the MC lagoon and the consequent overlapping of salinity distribution.

Particulate organic matter and $\mathrm{Chl}_{\mathrm{a}}$ comprise the main food sources for T. plebeius (Botto et al., 2005; Abrahão et al., 2010). Previous studies showed that $\mathrm{Chl}_{\mathrm{a}}$ remains high throughout the year along the MC coastal lagoon salinity gradient. Only a sharp decrease can be seen in winter (De Marco et al., 2005; Marcovecchio et al., 2006) and some sharp pulses may be detected in all seasons but only in the most inner areas (areas not sampled in this study; see De Marco et al., 2005). The results presented here corroborate this food availability for T. plebeius along the salinity gradient of MC coastal lagoon considered in this study. Regarding the other estuaries, SC falls into the reach of the turbidity front of the La Plata River (Acha et al., 2008). This implies that a great amount of food resources for suspension feeders, mostly as particulate organic matter but also phytoplankton (Acha et al., 2008), sustain a very productive trophic web in the area (Ieno and Bastida, 1998, Acha et al., 2008, Pájaro et al., 2008). Concerning BB estuary, a previous study showed high values of POM (Addino et al., 2015) when compared with those in MC (this study) and it is known that POM is correlated with the phytoplankton biomass in this area (Guinder et al., 2009). Thus, food availability would be neither a limiting factor nor the cause of smaller growth of clams in both the high salinity estuary (BB) and the low salinity estuary (SC) when compared with intermediate salinity estuary (MC).

As well as food availability, the results concerning temperature and sediment grain size did not show patterns that explain the differences found in clams' growth, morphology and condition index among study sites. These results suggest that, from the environmental variables measured in this study, only the salinity presents a gradient that could potentially distinguish study sites and could be related to changes in clams' shell characteristics. This is in accordance with previous studies with estuarine bivalves (e.g., Mytilus edulis, M. trossolus, Gardner and Thompson, 2001; Argopecten irradians, Shriver et al., 2002; Austrovenus stutchburyi, Marsden, 2004) showing that in a typical estuarine environmental gradient, salinity is the key factor that distinguishes among sites and is correlated with organisms' responses.

Morphology of infaunal bivalves may be related to sediment grain size and salinity. More elongated shells are typical of habitats with finer sediments (Eagar, 1978) given that it makes burrowing easier (Stanley, 1970); however, in this case there was not such a relationship since clams showed morphology differences among sites with the same sediment grain size. Instead, shells are more elongated in the sites with lower salinity in both scales of comparison (i.e., among estuaries and among sites within MC) and they become shorter as the salinity becomes higher. This is in accordance with that reported for the clams Rangia cuneata and Polymesoda caroliniana in the Río Caloosahatchee
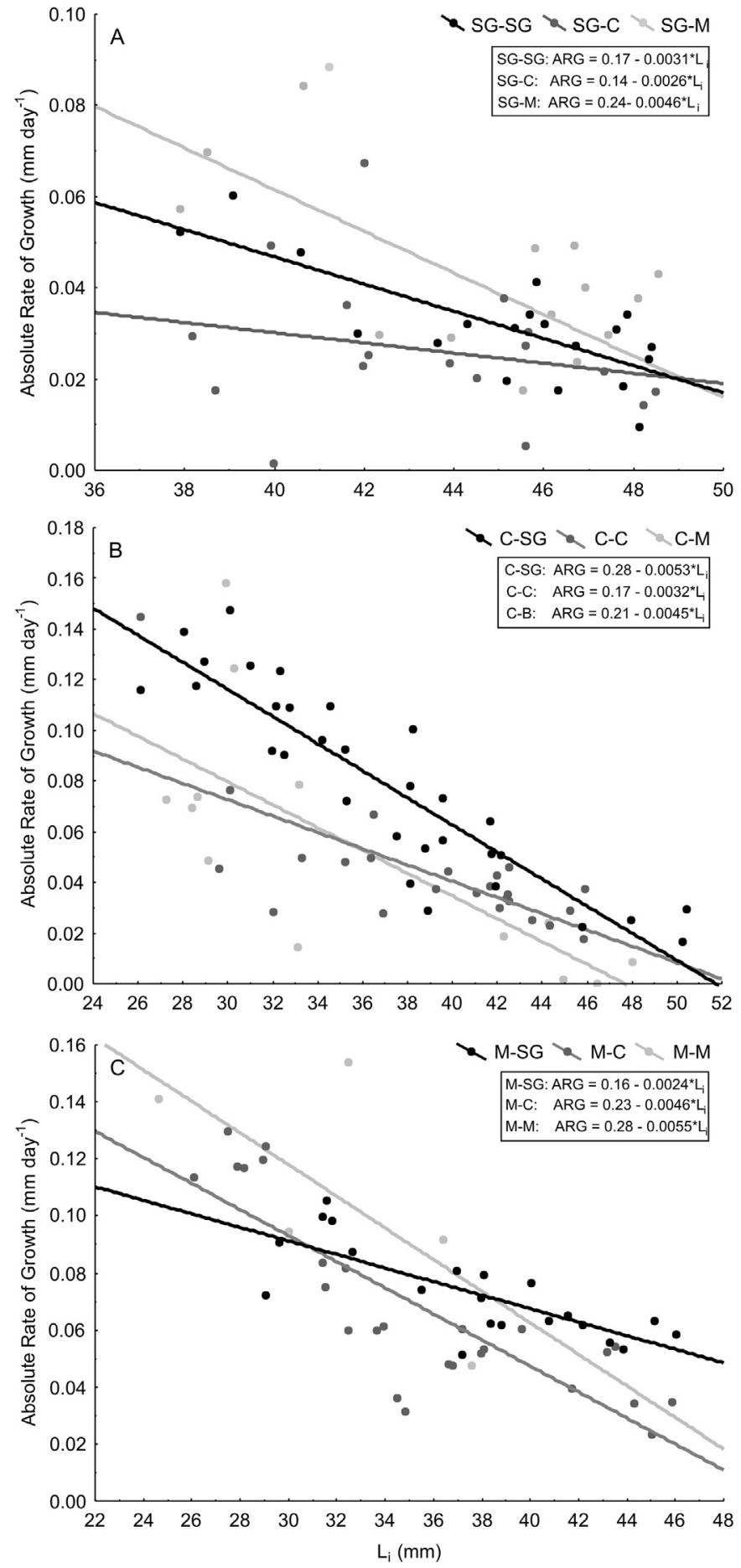

Fig. 6. Linear regression for initial length $\left(\mathrm{L}_{\mathrm{i}}\right)$ and Absolute Rate of Growth of transplanted clams. (A) Clams originally from San Gabriel (SG), (B) Clams originally from Celpa (C) and (C) Clams originally from Mouth (M). Capital letters in the top-right corner denote the origin-destination site, respectively, for each group of transplanted clams. (1 column).

estuary $\left(26^{\circ} 30^{\prime} \mathrm{N}, 82^{\circ} 10^{\prime} \mathrm{O}\right.$, Florida, USA, Barnes, 2005) where shell morphology and ornamentation are affected by the salinity changes.

The comparison of growth parameters at both regional and local scales are coincident showing higher growth rate $(\mathrm{k})$ and smaller asymptotic length $(\mathrm{L} \infty)$ in the areas with intermediate salinity. This higher growth rate was not related to temperature since sites with intermediate salinity showed lower or the same temperature when compared with other sites. Moreover, annual temperature ranges reported 
in the literature overlap among estuaries (SC: $8.2-23.3^{\circ} \mathrm{C}$, MC: $9-25^{\circ} \mathrm{C}$, BB: 8.5-21.6; see Piccolo and Perillo, 1997). Thus, differences in growth parameters are not related to temperature.

A previous study in MC showed somewhat different values for Tagelus plebeius $\mathrm{k}$ and $\mathrm{L} \infty(\mathrm{k}=0.181, \mathrm{~L} \infty=67.60$, Lomovasky et al., 2016) when compared with the present study. Nevertheless, these differences may be due to the use of clams pooled from different locations along the salinity gradient and with ages ranging from 0 to 27 years old, while the range of ages in this study was from 3 to 17. Even though the $\mathrm{k}$ and $\mathrm{L} \infty$ data indicate that the clams in sites with intermediate salinity reach smaller maximum sizes, it also may indicate an earlier and sudden transition between growing and reproduction (Thompson, 1979). That is, an earlier growing stop would result in higher energy availability for reproduction at an earlier age. Thus, a better reproductive performance would be related to the intermediate salinity.

The somatic tissue of organisms carries out all the physiological activity from basal metabolic maintenance to reproduction and growth (Dame, 1996). Thus, it is important to consider the condition index (CI) as representative of the physiological state for better data interpretation. As well as the shell growth, the CI pattern indicates a better individual state at intermediate salinity. Similar results were reported for the clam Austrovenus stutchburyi in the Avon-Heathcote estuary (New Zealand; Marsden, 2004) where environmental conditions (e.g., water depth, salinity range, sediment grain size, temperature) are similar to those reported here. Thus, both shell growth and individual somatic state indicate that the more favourable environments for Tagelus plebeius are those with intermediate salinity, as hypothesized.

Studies evaluating salinity effects on filtration rate (Nakamura et al., 2005), ingestion rate, absorption efficiency, faeces production (Gardner and Thompson, 2001) and, growth rate (Almada-Villela, 1984; Gardner and Thompson, 2001; Nakamura et al., 2005) agree that the organisms' response to changes in abiotic conditions are different depending on the origin of manipulated bivalves. Many other studies agree that a decrease in salinity is worse for bivalves' development than an increase (e.g., Choromytilus chorus, Navarro, 1988; Argopecten irradians, Shriver et al., 2002; Mactra veneriformis, Ruditapes philippinarum and Meretrix lusoria, Nakamura et al., 2005). For example, the scallop A. irradians showed lower shell growth with lower salinity (Cape Cod and Buzzards Bay, Massachusetts; Shriver et al., 2002) and those variables related to food did not explain the shell growth variability found (Shriver et al., 2002). The results of our transplant experiments agree with these evidences given that not all the sets of clams in a destination site (after transplant) responded in the same way; rather, it was different for clams from different origin. Moreover, high salinity was in general less harmful than low salinity; however, clams from the intermediate salinity site were negatively affected by both salinity extremes. Therefore, Tagelus plebeius in different estuaries will respond differently to salinity variations, but the sites that maintain or turn to intermediate salinity (e.g., after climatic events like the ENSO) would be more favourable for shell growth and condition state of these clams.

The findings of the present study show that salinity actually affects life-history traits of Tagelus plebeius, such as shell growth (and morphology) and individuals' condition, resulting in a better performance in intermediate salinity waters. The study area is affected by the ENSO cycle, which changes the rainfall pattern (Canepuccia et al., 2010) and freshwater inflow into these estuaries (Canepuccia et al., 2007) and thus, the salinity patterns (Piola et al., 2008). In this sense, and in the context of our findings, this clam may be affected by climatic events through changes in salinity. Future studies relating climatic events with changes in abiotic conditions and shell growth patterns of this species will be very useful for these vulnerable areas. Also, the study of other source of temporal fluctuation in salinity and other abiotic factors, in short as well as longer timescale, would be relevant in this context. Tagelus plebeius is the only native bivalve species inhabiting these intertidal zones, having an important role in different ecological processes and presenting great fossil abundance in Holocene outcrops.
Thus, the present findings highlight the effect that the changes in salinity may have in an important community component and indirectly in the entire community. Also, this study encourages the consideration of this clam as a valuable target for future studies on the field of conservation biology and paleobiology.

\section{Acknowledgements}

We thank to M. Eugenia Fanjul for her help in the field. We are also grateful to Fuerza Aérea Argentina of Mar del Plata for allowed us to work in C.E.L.P.A.

\section{Funding}

This work was supported by grants from Universidad Nacional de Mar del Plata (15/E214), FONCyT (PICT-2016-1445 to B.L.), CONICET (PIP No. 11220150100819) and by the German-Argentinean Bilateral Cooperation Program in Science and Technology (BMBF: ARG02-002 and MinCyT: AL/PA02-BI/002 and AL/09/06). M.S. Addino and M.F. Alvarez were supported by doctoral scholarships from CONICET and Universidad Nacional de Mar del Plata. This is part of the Doctoral thesis of M.S. Addino.

\section{References}

Abrahão, J.R., Cardoso, R.S., Yokoyama, L.Q., Amaral, A.C.Z., 2010. Population biology and secondary production of the stout razor clam Tagelus plebeius (Bivalvia, Solecurtidae) on a sandflat in southeastern Brazil. Zoologia 27, 54-64.

Acha, M., Mianzan, H., Guerrero, R., Carreto, J., Giberto, D., Montoya, N., Carignan, M., 2008. An overview of physical and ecological processes in the Rio de la Plata Estuary. Cont. Shelf Res. 28, 1579-1588.

Addino, M., 2014. Efecto de características físicas del ambiente e interacciones biológicas en los patrones de distribución e historia de vida de la almeja navaja Tagelus plebeius. Tesis de Doctorado. Universidad Nac. De Mar del Plata, Facultad de Cs. Exactas y Naturales, pp. 168

Addino, M., Lomovasky, B.J., Cremonte, F., Iribarne, O., 2010. Infection by gymnophallid metacercariae enhances predation mortality of SW Atlantic stout razor clam Tagelus plebeius. J. Sea Res. 63, 102-107.

Addino, M., Montemayor, D.I., Escapa, M., Alvarez, M.F., Valiñas, M.S., Lomovasky, B.J., Iribarne, O., 2015. Effect of Spartina alterniflora Loisel, 1807 on growth of the stout razor clam Tagelus plebeius (Lightfoot, 1786) in a SW Atlantic estuary. J. Exp. Mar. Biol. Ecol. 463, 135-142.

Addino, M., Alvarez, M.F., Iribarne, O., Lomovasky, B.J., 2016. Interaction between a mobile and a sessile species in SW Atlantic mudflats: lack of negative effects of the mud crab Cyrtograpsus angulatus Dana, 1851 on filtration rate and growth of the infalunal clam Tagelus plebeius (Lightfoot, 1786). J. Exp. Mar. Biol. Ecol. 476, 65-71.

Akaike, H., 1973. Information theory and an extension of the maximum likelihood principle. In: Petrov, B.N., Csaki, F. (Eds.), Second International Symposium on Information Theory. Akademiai Kiado, Budapest, pp. 267-281.

Almada-Villela, P.C., 1984. The effects of reduced salinity on the shell growth of Small Mytilus Edulis. J. Mar. Biol. Assoc. U. K. 64, 171-182.

Alvarez, M.F., Addino, M., Iribarne, O., Botto, F., 2015. Combined engineering effects of clams and crabs on infaunal assemblages and food availability in intertidal systems. Mar. Ecol. Prog. Ser. 540, 57-71.

Amarasekera, K.N., Lee, R.F., Williams, E.R., Eltahir, E.A.B., 1997. ENSO and the natural variability in the flow of tropical rivers. J. Hydrol. 200, 24-39.

Azouzi, L., Bourget, E., Borcard, D., 2002. Spatial variation in the intertidal bivalve Macoma balthica: biotic variables in relation to density and abiotic factors. Mar. Ecol. Prog. Ser. 234, 159-170.

Bachelet, G., 1980. Growth and recruitment of the tellinid bivalve Macoma balthica at the southern limit of its geographical distribution, the Gironde estuary (SW France). Mar. Biol. 59, 105-117.

Bachmann, S., Martínez, M.M., 1999. Feeding tactics of the American Oystercatcher (Haematopus palliatus) on Mar Chiquita coastal lagoon, Argentina. Ornitologia Neotropical 442, 81-84.

Barnes, T., 2005. Caloosahatchee estuary conceptual ecological model. Wetlands 25, $884-897$.

Bértola, G., 1994. Geomorfología y sedimentología de los ambientes mareales de la Bahía Samborombón (Prov. de Bs. As.). Tesis Museo de La Plata (200 pp).

Bértola, G.R., Cortizo, L., Pastorino, S., 1998. Delimitación de ambientes costeros en la bahía Samborombón mediante información satelitaria. Actas 5, 217-225.

Botto, F., Valiela, I., Iribarne, O., Martinetto, P., Alberti, J., 2005. Impact of burrowing crabs on $\mathrm{C}$ and $\mathrm{N}$ sources, control, and transformations in sediments and food webs of SW Atlantic estuaries. Mar. Ecol. Prog. Ser. 293, 155-164.

Bray, W.A., Lawrence, A.L., Leung-Trujillo, J.R., 1994. The effect of salinity on growth and survival of Penaeus vannamei, with observations on the interaction of IHHN virus and salinity. Aquaculture 122, 133-146.

Brescia, V., Lema, D., Parellada, G., Documento, D.T., 1998. El fenómeno ENSO y la 
agricultura pampeana: impactos económicos en trigo, maíz, girasol y soja. Vol. 1. Informe Técnico INTA, pp. 1-35.

Brown, J.R., 1988. Multivariate analyses of the role of environmental factor in seasonal and site-related growth variation in the Pacific oyster Crassostrea gigas. Mar. Ecol. Prog. Ser. 45, 225-236.

Bruschetti, M., Luppi, T., Fanjul, E., Rosenthal, A., Iribarne, O., 2008. Grazing effect of the invasive reef-forming polychaete Ficopomatus enigmaticus (Fauvel) on phytoplankton biomass in a SW Atlantic coastal lagoon. J. Exp. Mar. Biol. Ecol. 354, 212-219.

Canepuccia, A.D., Isacch, J.P., Gagliardini, D.A., Escalante, A.H., Iribarne, O., 2007. Waterbird response to changes in habitat area and diversity generated by rainfall in a SW Atlantic coastal lagoon. Waterbirds 30, 541-553.

Canepuccia, A.D., Alberti, J., Pascual, J., Alvarez, G., Cebrian, J., Iribarne, O., 2010. ENSO episodes modify plant/terrestrial-herbivore interactions in a southwestern Atlantic salt marsh. J. Exp. Mar. Biol. Ecol. 396, 42-47.

Cerrato, R.M., 1990. Interpretable statistical test for growth comparisons using parameters in the Von Bertalanffy equation. Can. J. Fish. Aquat. Sci. 47, 1416-1426.

Clausen, I., Riisgård, H., 1996. Growth, filtration and respiration in the mussel Mytilus edulis: no evidence for physiological regulation of the filter-pump to nutritional needs. Mar. Ecol. Prog. Ser. 141, 37-45.

Cruz-Vásquez, R., Rodríguez-Domínguez, G., Alcántara-Razo, E., Aragón-Noriega, E.A., 2012. Estimation of individual growth parameters of the Cortes Geoduck Panopea Gobosa from the central gulf of California using a multimodel approach. J. Shellfish Res. 31, 725-732.

Dame, R.F., 1996. Ecology of Marine Bivalves: An Ecosystem Approach. CRC Press, Boca Raton, Fl, USA 253 pp.

De Marco, S.G., Beltrame, M.O., Freije, R.H., Marcovecchio, J.E., 2005. Phytoplankton dynamic in Mar Chiquita Coastal Lagoon (Argentina), and its relationship with potential nutrient sources. J. Coast. Res. 21, 818-825.

Eagar, R.M.C., 1978. Shape and function of the shell: a comparison of some living and fossil bivalve mollusks. Biol. Rev. 53, 169-210.

Forster, S., Zettler, M., 2004. The capacity of the filter-feeding bivalve Mya arenaria L. to affect water transport in sandy beds. Mar. Biol. 144, 1183-1189.

Franklin, A.B., Shenk, T.M., Anderson, D.R., Burnham, K.P., 2001. Statistical model selection: an alternative to null hypothesis testing. In: Shenk, T.M. y Franklin, A.B. Modeling in Natural Resource Management: Development, Interpretation and Application. Washington, DC: Island Press, pp. 75-90.

Garcia, A.M., Vieira, J.P., Winemiller, K.O., Grimm, A.M., 2004. Comparison of 1982-1983 and 1997-1998 El Niño effects on the shallow-water fish assemblage of the Patos Lagoon estuary (Brazil). Estuaries 27, 905-914.

Gardner, J.P.A., Thompson, R.J., 2001. The effects of coastal and estuarine conditions on the physiology and survivorship of the mussels Mytilus edulis, M.trossulus and their hybrids. J. Exp. Mar. Biol. Ecol. 265, 119-140.

Gosling, E., 2003. Bivalve Molluscs. Biology, Ecology and Culture. Blackwell Publishing Ltd, Oxford, UK.

Grimm, A.M., Tedeschi, R.G., 2009. ENSO and extreme rainfall events in South America. J. Clim. 22, 1589-1609.

Grimm, A.M., Barros, V.R., Doyle, M.E., 2000. Climate variability in southern South America associated with El Niño and La Niña events. J. Clim. 13, 35-58.

Guinder, V.A., Popovich, C.A., Perillo, G.M.E., 2009. Particulate suspended matter concentrations in the Bahía Blanca Estuary, Argentina: Implication for the development of phytoplankton blooms. Estuar. Coast. Shelf Sci. 85, 157-165.

Gutierrez, J., Iribarne, O.O., 2004. Conditional responses of organisms to habitat structure: an example from intertidal mudflats. Oecologia 139, 572-582.

Gutierrez, J., Iribarne, O., 1999. Role of Holocene beds of the stout razor clam Tagelus plebeius in structuring present benthic communities. Mar. Ecol. Prog. Ser. 185, 213-228.

Hawkins, A.J.S., Bayne, B.L., 1992. Physiological interrelations and the regulation of production. In: Gosling, E. (Ed.), The Mussel Mytilus: Ecology, Physiology, Genetics and Culture. Elsevier, Amsterdan (122-171 pp.).

Holland, A.F., Dean, J.M., 1977. The biology of the stout razor clam Tagelus plebeius: I. Animal-sediment relationships, feeding mechanism, and community biology. Chesap. Sci. 18, 58-66.

Ieno, E.N., Bastida, R.O., 1998. Spatial and temporal patterns in coastal macrobenthos of Samborombon Bay, Argentina: a case study of very low diversity. Estuaries 21, 690-699.

Iribarne, O., Valero, J., Martinez, M.M., Lucifora, L., Bachmann, S., 1998. Shorebird predation may explain the origin of Holocene beds of stout razor clams in life position. Mar. Ecol. Prog. Ser. 167, 301-306.

Isacch, J.P., Costa, C.S.B., Rodriguez-Gallego, L., Conde, D., Escapa, M., Gagliardini, D.A., Iribarne, O.O., 2006. Distribution of saltmarsh plant communities associated with environmental factors along a latitudinal gradient on the south-West Atlantic coast. J. Biogeogr. 5, 888-900.

Isla, F.I., Gaido, E.S., 2001. Evolución geológica de la laguna Mar Chiquita. In: Iribarne, O. (Ed.), Reserva de biósfera Mar Chiquita: Características físicas, biológicas y ecológicas. Editorial Martín, Mar del Plata (319 pp.).

Jones, D.S., Quitmyer, I.R., Arnold, W.S., Marelli, D.C., 1990. Annual shell banding, age, and growth rate of hard clams (Mercenaria spp.) from Florida. J. Shellfish Res. 9, 215-225.

Jones, C.G., Lawton, J.H., Shachak, M., 1994. Organisms as ecosystem engineers. Oikos 69, 373-386.

Klein, R., 1996. Sr/Ca and ${ }^{13} \mathrm{C} /{ }^{12} \mathrm{C}$ ratios in skeletal calcite of Mytilus trossulus: Covariation with metabolic rate, salinity, and carbon isotopic composition of seawater. Geochim. Cosmochim. Acta 60, 4207-4221.

Lanfredi, N.W., Balestrini, C.F., Mazio, C.A., Schmidt, S.A., 1981. Tidal sandbanks in Mar Chiquita coastal Lagoon, Argentina. J. Coast. Res. 3, 515-520.

Leal, J.H., 2002. Bivalvia. In: Carpenter, K.E. (Ed.), The Living Marine Resources of the
Western Central Atlantic. I: Introduction, Mollusks, Crustaceans, Hagfishes, Sharks, Batoid Fishes and Chimaeras. FAO Identification Guide for Fishery Purposes. FAO, Rome, pp. 25-98.

Leguerrier, D., Niquil, N., Boileau, N., Rzeznik, J., Suriau, P., Moine, O., Bacher, C., 2003. Numerical analysis of the food web of an intertidal mudflat ecosystem on the Atlantic coast of France. Mar. Ecol. Prog. Ser. 246, 17-37.

Lenihan, H.S., Peterson, C.H., Allen, J.M., 1996. Does flow speed also have a direct effect on growth of active suspension-feeders: an experimental test on oysters. Limnol. Oceanogr. 41, 1359-1366.

Lomovasky, B.J., Gutiérrez, J.L., Iribarne, O., 2005. Identifying repaired shell damage and abnormal calcification in the stout razor clam Tagelus plebeius as a tool to investigate its ecological interactions. J. Sea Res. 54, 163-175.

Lomovasky, Betina J., Mendez Casariego, A., Brey, T., Iribarne, O., 2006. The effect of the SW Atlantic burrowing crabs Chasmagnathus granulatus on the intertidal razor clam Tagelus plebeius. J. Exp. Mar. Biol. Ecol. 337, 19-29.

Lomovasky, B.J., Brey, T., Klügel, A., Iribarne, O., 2016. Distribution Pattern, Density and Growth of the Stout Razor Clam Tagelus plebeius in a Southwest Atlantic Estuarine System. J. Mar. Biol. Assoc. U. K. https://doi.org/10.1017/S0025315416001715.

Marcovecchio, J., Freije, H., De Marco, S., Gavio, A., Ferrer, L., Andrade, S., Beltrame, O., Asteasuain, R., 2006. Seasonality of hydrographic variables in a coastal lagoon: Mar Chiquita, Argentina. Aquatic conservation. Vol. 16. pp. 335-347.

Marsden, I., 2004. Effects of reduced salinity and seston availability on growth of the New Zealand little-neck clam Austrovenus stutchburyi. Mar. Ecol. Prog. Ser. 266, 157-171.

Martínez, S., Del Río, C., 2005. Las ingresiones marinas del Neógeno en el sur de Entre Ríos (Argentina) y Litoral Oeste de Uruguay y su contenido malacológico. Miscelánea $14,13-26$.

Menafra, R., Rodríguez-Gallego, L., Scarabino, F., Conde, D., 2006. Bases para la conservación y el manejo de la costa uruguaya. Vida Silvestre Uruguay, Montevideo.

Molles, M.C., 2002. Ecology. Concepts and Applications. McGraw-Hill Companies Inc, New York, USA.

Montagna, P.A., Estevez, E.D., Palmer, T.A., Flannery, M.S., 2008. Meta-analysis of the relationship between salinity and molluscs in tidal river estuaries of Southwest Florida. U.S.A. Am. Malacol. Bull. 24, 101-115.

Nakamura, Y., Hashizume, K., Koyama, K., Tamaki, A., 2005. Effects of salinity on sand burrowing activity, feeding and growth of the clams Mactra veriformis, Ruditapes philippinarum and Meretrix lusoria. J. Shellfish Res. 24, 1053-1059.

Navarro, J.M., 1988. The effects of salinity on the physiological ecology of Choromytilus chorus (Molina, 1782) (Bivalvia: Mytilidae). J. Exp. Mar. Biol. Ecol. 122, 19-33.

Newell, C.R., 1991. The soft shell clam Mya arenaria (Linnaeus) in North America. In: Menzel, W. (Ed.), Estuarine and marine mollusk culture. CRC Press, Boca Raton, FL, pp. $1-10$.

Norkko, J., Thrush, S.F., Wells, R.M., 2006. Indicators of short-term growth in bivalves: Detecting environmental change across ecological scales. J. Exp. Mar. Biol. Ecol. 337, $38-48$.

Olivier, S.R., Escofet, A., Penchaszadeh, P., Orensanz, J.M., 1972. Estudio ecológicos de la región estuarial de Mar Chiquita (Buenos Aires, Argentina). I: Las comunidades bentónicas. Anales de la Sociedad Científica Argentina Vol. 193, 237-262.

Pájaro, M., Martos, P., Leonarduzzi, E., Macchi, G.J., Diaz, M.V., Brown, D., 2008. Estrategia de puesta de la anchoíta (Engraulis anchoíta) en el mar argentino y zona común de pesca argentino-uruguaya. INIDEP Informe Técnico Oficial 011. pp. 14.

Perillo, G.M.E., Piccolo, M.C., 1999. Geomorphologic and physical characteristics of the Bahía Blanca estuary, Argentina. In: Perillo, G.M.E., Piccolo, M.C., Pino Quivira, M. (Eds.), Estuaries of South America: Their Geomorphology and Dynamics. Environmental Science Series. Springer, Berlín, Germany.

Piccolo, M.P., Perillo, G.M.E., 1997. El mar argentino y sus recursos pesqueros, Tomo 1, Antecedentes históricos de las exploraciones en el mar y las características ambientales. In: Geomorfología e hidrografía de los estuarios. En: Boschi E.E. (ed). Vol. 1. Instituto Nacional de Investigación y Desarrollo Pesquero. Secretaría de Agricultura, Ganadería, Pesca y Alimentación, pp. 133-161 Mar del Plata, República Argentina.

Piola, A.R., Romero, S.I., Zajaczkovski, U., 2008. Space-time variability of the Plata plume inferred from ocean color. Cont. Shelf Res. 28, 1556-1567.

Reta, R., Martos, P., Perillo, G.M.E., Piccolo, C., Ferrante, A., 2001. Características hidrográficas del estuario de la laguna Mar Chiquita. In: Iribarne, O. (Ed.), Reserva de biósfera Mar Chiquita: Características físicas, biológicas y ecológicas. Editorial Martín, Mar del Plata (319 pp).

Richardson, C.A., 2001. Molluscs as archives of environmental change. Oceanogr. Mar. Biol. 39, 103-164.

Ricker, W.E., 1975. Computation and interpretation of biological statistics of fish populations. Bull. Fish. Res. Board Can. 191, 1-382.

Saxby, A., 2002. A review of food availability, sea water characteristics and bivalve growth performance at coastal culture sites in temperate and warm temperate regions of the world. Fish. Res. Rep. 132.

Schnack, J.E., Fasano, J.L., Isla, F.I., 1982. The evolution of Mar Chiquita lagoon, Province of Buenos Aires, Argentina. In: Colquhoun, D.J. (Ed.), Holocene Sea-Level Fluctuations: Magnitudes and Causes. IGCP 61, Univ. South Carolina, Columbia Press, pp. 143-155.

Seitz, R., Lipcius, R., Olmstead, N., Seebo, M., Lambert, D., 2006. Influence of shallowwater habitats and shoreline development on abundance, biomass, and diversity of benthic prey and predators in Chesapeake Bay. Mar. Ecol. Prog. Ser. 326, 11-27.

Shriver, A.C., Carmichael, R.H., Valiela, I., 2002. Growth, condition, reproductive potential, and mortality of bay scallops, Argopecten irradians, in response to eutrophicdriven changes in food resources. J. Exp. Mar. Biol. Ecol. 279, 21-40.

Stanley, S.M., 1970. Relation of shell form to life habits in the Bivalvia. Geol. Soc. Am. Mem. 125, 1-296.

Thompson, R.J., 1979. Fecundity and reproductive efffort in the blue mussel (Mytilus edulis), the sea urchin (Strongylocentrotus droebachiensis), and the snow crab 
(Chionoecetes opilio) from populations in Nova Scotia and Newfoundland. J. Fish. Res. Board Can. 36, 955-964.

Vázquez, N., Ituarte, C., Navone, G., Cremonte, F., 2006. Parasites of the stout razor clam Tagelus plebeius (Psammobiidae) from the Southwestern Atlantic Ocean. J. Shellfish Res. 25, 877-886.

Volety, A.K., 1995. A Study of the Histozoic Oyster Parasite, Perkinsus marinus: I. Disease Processes in American Oysters, II. Biochemistry of P. marinus. Ph. D. dissertation.
College of William and Mary, Virginia Institute of Marine Science, Williamsburg, VA, USA.

Von Bertalanffy, L., 1938. A quantitative theory of organic growth. Hum. Biol. 10, $181-213$.

Zar, J.H., 1999. Biostatistical Analysis, 4th edition. Prentice-Hall, Inc, Englewood Cliffs, NJ, pp. 718. 